\title{
Widespread detection of Phytophthora taxon Salixsoil in the littoral zone of Lake Constance, Germany
}

\author{
Jan Nechwatal* and Kurt Mendgen \\ Universität Konstanz, Phytopathologie, D-78457, Konstanz, Germany \\ *Author for correspondence (Fax: +49-7531-883035; E-mail: jan.nechwatal@uni-konstanz.de)
}

Accepted 23 November 2005

Key words: clade 6, Phragmites australis, Phytophthora gonapodyides, root pathogen

\begin{abstract}
An unnamed ITS clade 6 Phytophthora was frequently isolated from rhizosphere soil of reed (Phragmites australis) growing on the littoral zone of Lake Constance. The isolates closely resembled $P$. gonapodyides, having internally proliferating, non-papillate sporangia, a rather high temperature optimum for growth $\left(30^{\circ} \mathrm{C}\right)$, and being sexually sterile. ITS sequence analysis revealed that they were identical to the as yet unnamed Phytophthora taxon Salixsoil, originally isolated from Salix roots in the UK and Alnus debris in Denmark. The taxon was readily isolated from permanently as well as occasionally flooded reed sites using standard baiting procedures, indicating a wide distribution in the Lake Constance littoral zone. In an in vitro leaf inoculation assay $P$. taxon Salixsoil proved to be more aggressive towards Salix alba than $P$. gonapodyides. The new taxon may be of significance as a root pathogen of woody plants in moist or flooded situations occurring in alluvial forest/plant communities. We propose that due to its close resemblance to $P$. gonapodyides the taxon might have passed unnoticed in the past, and possibly is much more widely distributed than previously recognised.
\end{abstract}

Phytophthora species are among the most destructive pathogens of agricultural crop plants world-wide. During the last decade, a series of devastating diseases of several tree species has also focused attention on the importance of these pathogens in natural and semi-natural ecosystems. This has led to the identification of several new Phytophthora spp. from forests and riparian ecosystems causing fine root diseases, collar rot or bleeding cankers in several woody hosts (e.g. Jung et al., 2003; Brasier et al., 2004). As the life cycle of Phytophthora spp. is usually dependent on the presence of water for the dispersal of zoospores and other sources of inoculum, semiterrestrial sites, in particular in riparian areas of lakes and streams are likely to harbour a diverse, not yet fully investigated flora of these 'fungi'. They may play a major role in the breakdown of plant litter, but may also be pathogens of considerable significance (Brasier et al., 2003). In the course of a study on the occurrence and diversity of oomycete species in reed stands (Phragmites australis [Poaceae]) of Lake Constance (Germany) a previously unnamed Phytophthora sp. from ITS clade 6 of Cooke et al. (2000) was consistently isolated from reed rhizosphere soil samples. This paper reports on the first results regarding identity, pathogenicity and ecology of this taxon.

Reed rhizosphere soil samples were taken during summer 2003 from permanently flooded $(n=8)$ as well as from only occasionally flooded habitats $(n=6)$ on several sites at the Lake Constance littoral zone $\left(9^{\circ} 11^{\prime} 18^{\prime \prime} \mathrm{E}, 47^{\circ} 41^{\prime} 53^{\prime \prime} \mathrm{N}\right)$. Conventional baiting techniques with young oak leaflets were applied for the isolation of Phytophthora spp. (Jung et al., 2003). Infected baits were plated on PARNP agar plates (Tsao, 1983) and inspected daily for the appearance of Phytophthora 
Table 1. Sporangial dimensions of Phytophthora taxon Salixsoil and P. gonapodyides

\begin{tabular}{llr}
\hline & $P$. taxon Salixsoil & ${\text { P. } \text { gonapodyides }^{\mathrm{a}}}^{\mathrm{a}}$ \\
\hline Length $(\mu \mathrm{m})$ & $44.3 \mathrm{a}(35.8-51.3)$ & $53.7 \mathrm{~b}(49.6-59.8)$ \\
Breadth $(\mu \mathrm{m})$ & $31.2 \mathrm{a}(26.8-38.5)$ & $37.7 \mathrm{~b}(36.6-39.7)$ \\
L/B ratio & $1.42 \mathrm{a}(1.34-1.68)$ & $1.43 \mathrm{a}(1.27-1.64)$ \\
\hline
\end{tabular}

${ }^{\mathrm{a}}$ Mean and range of 11 isolates (UKN1, 3, 4, 5, 6, 7, 8, 9, 14, 15, H16/02).

${ }^{\mathrm{b}}$ Mean and range of 10 isolates (UKN-GON1, 2, 3, 4, 5, IFB-GON2, 3, 8, ATCC46726, IMI340619).

Isolate sources: ATCC, American Type Culture Collection, USA; H, Institute of Plant Protection, Budapest, Hungary; IFB, Technische Universität München, WZW, Pathology of Forest Trees, Freising, Germany; IMI, CABI Bioscience, UK; UKN, Universität Konstanz, Phytopathology, Konstanz, Germany.

Means within rows followed by the same letter are not significantly different $(P \leq 0.01$, unpaired $T$-test).

cultures. For the assessment of daily growth rates the purified Phytophthora isolates were plated onto CMA, V8A, and MEA plates $(20 \mathrm{ml})$ and incubated at $6,10,15,19,24,30,33,37$ and $40{ }^{\circ} \mathrm{C}$ for several days. Molecular identification was done by sequencing PCR-generated fragments of the ITS1, 5.8S and ITS2 of the rDNA repeat, using the primers ITS6 and ITS4 (White et al., 1990; Cooke and Duncan, 1997). BLAST searches of the GenBank nucleotide database (http://www.ncbi.nlm.nih.gov) revealed the most closely related known species. Based on the ITS sequence data obtained and alignments with other Phytophthora sequences, a specific primer pair was constructed to allow for the cultureindependent detection in environmental samples (Ph1-Fw: 5'-CTATAATTCGGGGGCTTGCTC-3'; Ph1-Rev: 5'-GTTCATACCGCTGCAGCAGG-3'). A touchdown PCR protocol $\left(30 \mathrm{~s}\right.$ at $94{ }^{\circ} \mathrm{C}, 15 \mathrm{~s}$ at $75{ }^{\circ} \mathrm{C}$ with a decrease of $1{ }^{\circ} \mathrm{C}$ per cycle for 10 cycles, followed by 39 cycles of $30 \mathrm{~s}$ at $94{ }^{\circ} \mathrm{C}, 15 \mathrm{~s}$ at $65{ }^{\circ} \mathrm{C}$ and $30 \mathrm{~s}$ at $72{ }^{\circ} \mathrm{C}$ ) was found to be best suited for specific and sensitive primer performance. A combination of baiting and PCR techniques as described earlier (Nechwatal et al., 2001) was then applied to detect the taxon in soil samples taken along a spatial gradient on the littoral zone of Lake Constance, ranging from flooded riparian sites to a neighbouring forest stand. In order to test the pathogenicity of the taxon towards reed, and to reveal its pathogenic potential in relation to its close relative $P$. gonapodyides $(\mathrm{PG})$, in vitro leaf infection assays were performed. Pathogenicity was tested by placing colonised agar discs from actively growing cultures of five $P$. taxon Salixsoil isolates on 12 young, greenhouse-grown reed leaves or 11 leaves collected from a single Salix alba tree in the field. Leaves were kept for one week in sealed
Petri dishes on moist filter paper in the dark at $24^{\circ} \mathrm{C}$. Lesion size was evaluated using ASSESS (APS, St. Paul, USA) by means of a scanner. In the Salix leaf tests five isolates of PG were included for comparison. The tests were repeated three times per isolate.

Phytophthora spp. were isolated from 7 out of the 14 rhizosphere soil samples in reed stands (5 flooded, 2 drier sites). All isolates closely resembled $P$. gonapodyides, having PG colony type, internally proliferating, non-papillate sporangia, and being sexually sterile. However, they had unusually high optimum and maximum temperatures for growth $\left(30\right.$ and $37^{\circ} \mathrm{C}$, respectively), and sporangia were smaller than those of PG as judged by comparison with a collection of PG isolates (Table 1). Variation in sporangial size of PG was also reported in the study of Brasier et al. (1993), and Brasier et al. (2003) broke down 'PG' isolates into several morphologically similar taxa. Sequence analysis revealed that all isolates from our study were identical to the as yet unnamed ITS clade 6 Phytophthora taxon Salixsoil, originally isolated from diseased Salix roots in the UK and Alnus root debris in Denmark, and informally named by Brasier et al. (2003). The ITS sequence uniformity shown here is further evidence that this taxon represents a new, distinct species that awaits formal description. No dimorphic sites were observed in the sequence electropherograms, and a single representative sequence has been submitted to GenBank (AY762973). In an alignment comprising $820 \mathrm{bp}$, the taxon differed from its closest described relative, PG, by 22 positions $(97 \%$ identity). Several other as yet undescribed close relatives from ITS clade 6 are reported by Brasier et al. (2003).

ITS sequence alignments with other Phytophthora spp. allowed the design of $P$. taxon 
Salixsoil-specific primers for the culture-independent detection of the species. The primers did not amplify DNA of the closely related PG and 12 other Phytophthora spp. A combination of oak leaflet baiting and PCR techniques (Nechwatal et al., 2001) proved the taxon's close association with moist or flooded sites. It was only detected in (temporarily) flooded littoral soils, but not in the more elevated sites of the neighbouring mixed forest stand (data not shown). The habitat fits well with those previously reported for this taxon, i.e. wet and flooded soil conditions or leaf debris in ponds (Brasier et al., 2003). The ease of isolation and detection of the taxon with standard baiting and PCR techniques indicates the abundance of $P$. taxon Salixsoil in the investigated stands.

Although widespread in the reed belt, $P$. taxon Salixsoil was non-pathogenic towards $P$. australis, the predominating plant in these sites. The taxon did not cause any lesions, even when inoculated onto artificially wounded leaf blades. However, it readily colonised dead reed leaf material floating in littoral lake water (Nechwatal et al., unpubl.). This saprophytic potential on gramineous plant tissue may ensure the taxon's survival and spread in these stands. Although only few records proved Phytophthora spp. to be pathogenic towards members of the grass family (e.g. Larsson and Gerhardson, 1990) a potential role as a root/leaf pathogen of reed cannot be ruled out and requires further investigation.

Leaves of $S$. alba were used in an in vitro infection assay to reveal the pathogenicity of the new taxon in comparison to PG. Disease incidence caused by five isolates of $P$. taxon Salixsoil was higher, and mean lesion size significantly larger than that caused by five PG isolates (Table 2). PG hardly caused any lesions on the leaves. No lesions developed on control leaves. Although a detached leaf assay may not be relevant to evaluate the pathogenic significance of a root pathogen under field conditions, these tests still demonstrate the potential pathogenicity of $P$. taxon Salixsoil towards an important woody species from alluvial forest ecosystems. Along with its exclusive occurrence in the investigated stands (no other Phytophthora spp. were found) our results suggest that the taxon might inhabit the same niches as PG and, as the latter, act as a root pathogen of woody plants under moist soil conditions (see also Brasier et al., 1993). Indeed, due to their strikingly similar morphology, an unknown number of isolates from such sites originally designated as PG might in fact be $P$. taxon Salixsoil. Thus, the new taxon might be much more widely distributed than previously reported.

Although sporangial size and maximum growth temperature may be useful as distinctive features, and thorough morphological examinations are likely to reveal other discriminating traits, a reexamination of PG isolates on a molecular basis that would elucidate this issue should precede a formal description of the species. This would also reveal valuable information on genetical variation and global distribution of this new species. Considering the fact that isolates of $P$. taxon Salixsoil have been obtained from the UK, from Denmark (Brasier et al., 2003), from riparian soils in Hungary (József Bakonyi, Plant Protection Institute, Hungary, pers. comm.) and from a stem necrosis of a peach tree in Southern Italy (Brasier et al., 2003; Santa Olga Cacciola, University of Palermo, Italy, pers. comm.), the taxon seems to be fairly widespread in Europe, and associated with different woody hosts, even under very diverse environmental conditions.

Table 2. Disease incidence and lesion size caused by five isolates of Phytophthora taxon Salixsoil, and five isolates of P. gonapodyides on leaves $(n=11)$ of Salix alba

\begin{tabular}{lll}
\hline & $P$. taxon Salixsoil ${ }^{\mathrm{a}}$ & ${\text { P. } \text { gonapodyides }^{\mathrm{b}}}$ \\
\hline Disease incidence $(\%$ infected leaves $)$ & $34 \mathrm{a}$ & $3 \mathrm{~b}$ \\
Mean lesion size $\left(\mathrm{mm}^{2}\right)$ (standard error) & $40.8 \mathrm{a}(8.7)$ & $10.8 \mathrm{~b}(2.2)$ \\
Mean lesion size $(\%$ of total leaf size $)$ & $8.2 \mathrm{a}$ & $1.8 \mathrm{~b}$ \\
\hline
\end{tabular}

${ }^{\mathrm{a}}$ Mean of five isolates (UKN1, 4, 6, 14, H16/02).

${ }^{\mathrm{b}}$ Mean of five isolates (UKN-GON2, IFB-GON2, 3, ATCC46726, IMI340619).

Isolate sources: ATCC, American Type Culture Collection, USA; H, Institute of Plant Protection, Budapest, Hungary; IFB, Technische Universität München, WZW, Pathology of Forest Trees, Freising, Germany; IMI, CABI Bioscience, UK; UKN, Universität Konstanz, Phytopathology, Konstanz, Germany.

Means within rows followed by the same letter are not significantly different ( $P \leq 0.01$, unpaired $T$-test, or Mann-Whitney Test). 


\section{Acknowledgements}

This study was funded by the Deutsche Forschungsgemeinschaft (DFG), as part of the SFB 454 ('Littoral Zone of Lake Constance'). We thank Thomas Jung (Freising, Germany) and József Bakonyi (Budapest, Hungary) for providing additional isolates.

\section{References}

Brasier CM, Hamm PB and Hansen EM (1993) Cultural characteristics, protein patterns and unusual mating behaviour of Phytophthora gonapodyides isolates from Britain and North America. Mycological Research 97: 1287-1298.

Brasier CM, Cooke DEL, Duncan JM and Hansen EM (2003) Multiple new phenotypic taxa from trees and riparian ecosystems in Phytophthora gonapodyides-P. megasperma ITS clade 6, which tend to be high-temperature tolerant and either inbreeding or sterile. Mycological Research 107: 277290.

Brasier CM, Kirk SA, Delcan J, Cooke DEL, Jung T and Man In't Veld WA (2004) Phytophthora alni sp. nov. and its variants: Designation of emerging heteroploid hybrid pathogens spreading on Alnus trees. Mycological Research 108: 1172-1184.
Cooke DEL and Duncan JM (1997) Phylogenetic analysis of Phytophthora species based on ITS1 and ITS2 sequences of the ribosomal RNA gene repeat. Mycological Research 101: 667-677.

Cooke DEL, Drenth A, Duncan JM, Wagels G and Brasier CM (2000) A molecular phylogeny of Phytophthora and related oomycetes. Fungal Genetics \& Biology 30: 17-32.

Jung T, Nechwatal J, Cooke DEL, Hartmann G, Blaschke M, Osswald W, Duncan J and Delatour C (2003) Phytophthora pseudosyringae sp. nov., a new species causing root and collar rot of deciduous tree species in Europe. Mycological Research 107: 772-789.

Larsson M and Gerhardson B (1990) Isolates of Phytophthora cryptogea pathogenic to wheat and some other crop plants. Journal of Phytopathology 129: 303-315.

Nechwatal J, Schlenzig A, Jung T, Cooke DEL, Duncan JM and Osswald WF (2001) A combination of baiting and PCR techniques for the detection of Phytophthora quercina and $P$. citricola in soil samples from oak stands. Forest Pathology 31: 85-97.

Tsao PH (1983). Factors affecting isolation and quantification of Phytophthora from soil. In: Erwin DC, Bartnicki-Garcia S and Tsao PH (eds.) Phytophthora: Its Biology, Taxonomy, Ecology, and Pathology (pp. 219-236) APS Press, St. Paul.

White TJ, Bruns T, Lee S and Taylor J (1990). Amplification and direct sequencing of fungal ribosomal RNA genes for phylogenetics. In: Innis MA, Gelfand DH, Sninsky JJ and White TJ (eds.) PCR Protocols: A Guide to Methods and Applications (pp. 315-322) Academic Press, San Diego. 